\title{
Mangromicins, six new anti-oxidative agents isolated from a culture broth of the actinomycete, Lechevalieria aerocolonigenes K10-0216
}

\begin{abstract}
Takuji Nakashima ${ }^{1}$, Yoshiyuki Kamiya ${ }^{2}$, Masato Iwatsuki ${ }^{2,3}$, Yōko Takahashi ${ }^{2,3}$ and Satoshi Ōmura ${ }^{3}$
We have been continually searching for novel chemical compounds from culture broths of various actinomycetes using a physicochemical screening system. During the course of this program, we have previously reported the discovery of two new natural products, designated mangromicins $\mathrm{A}$ and $\mathrm{B}$, discovered in a broth of a rare actinomycete strain, Lechevalieria aerocolonigenes $\mathrm{K} 10-0216$. Mangromicins have a unique and rare structure, a cyclopentadecane skeleton with a tetrahydrofuran unit and a 5,6-dihydro-4-hydroxy-2-pyrone moiety. New mangromicin analogs were isolated by using an improved production medium. As a consequence, six analogs, together with mangromicins $A$ and $B$, were isolated from a cultured broth of $L$. aerocolonigenes K10-0216. We named them mangromicins D, E, F, G, H and I. All mangromicins showed radical scavenging activities against 1,1-diphenyl-2-picrylhydrazyl (DPPH) free radicals and nitric oxide generated from LPS-stimulated RAW264.7 cells, a murine macrophage cell line. Among the analogs, mangromicins A and I showed the most potent DPPH radical scavenging activity and nitric oxide scavenging activity, respectively.
\end{abstract}

The Journal of Antibiotics (2014) 67, 533-539; doi:10.1038/ja.2014.34; published online 2 April 2014

Keywords: actinomycete strain; Lechevalieria aerocolonigenes; Mangromicins; radical scavenging activity

\section{INTRODUCTION}

Of the 1073 small molecule organic compounds introduced worldwide as drugs during the period 1981-2010, 66\% were natural products, derivatives or mimics of natural products. ${ }^{1}$ Natural products from microbial cultured broths have been screened by bioassay programs to identify useful bioactivity properties. $^{2}$ Many bioactive compounds have been discovered by this approach, such as kanamycin, ${ }^{3}$ leucomycin ${ }^{4}$ and avermectin, ${ }^{5}$ all well-known useful compounds of microbial metabolite origin. However, the search for new compounds from microorganisms is often criticized for resulting in the re-discovery, re-isolation and re-characterization of previously known compounds. Therefore, it is important to avoid this duplication as early as possible in the process.

We have discovered new natural products, trehangelins ${ }^{6}$ and mangromicins, ${ }^{7}$ from culture broths of microorganisms using physicochemical (PC) screening. As PC screening is a method utilizing the PC properties of compounds, such as polarity, molecular formula and UV spectra, this screening method does not depend on biological activity. The search for new compounds via this screening system is guided by liquid chromatography-UV detection (LC/UV), liquid chromatography-MS (LC/MS), and color reaction (for example, detection of alkaloids by Dragendorff's reagent).
We constructed an in-house database based on the PC data of various known compounds in microbial culture broths. Using this database and external databases, such as the Dictionary of Natural Products (http://dnp.chemnetbase.com/), a cultured broth that was predicted to contain new compounds was selected. The structure elucidation of new compounds that were isolated from the cultured broth was carried out. Subsequently, the purified new compound was investigated for biological activities (antimicrobial, antitumor, antiparasitic activities, etc.) by specific customized bioassays.

PC screening system has already identified several new natural compounds, for example, staurosporine, ${ }^{8}$ dityromycin ${ }^{9}$ and trehangelins. ${ }^{6}$ Mangromicins A (1) and B (2) were also discovered from a cultured broth of the actinomycete species, Lechevalieria aerocolonigenes K10-0216, isolated from mangroves in Iriomote Island, Okinawa prefecture, Japan (Figure 1).,10,11 Mangromicins have a unique cyclopentadecane skeleton with a tetrahydrofurane unit and a 5,6-dihydro-4-hydroxy-2-pyrone moiety. Moreover, we discovered six new analogs (mangromicins D-I (3-8)) from a broth of same strain K10-0216 using an improved production medium. ${ }^{12}$ In this study, we report the fermentation, isolation, structure elucidation and anti-oxidative activities of these mangromicin analogs.

${ }^{1}$ Research Organization for Infection Control Sciences, Kitasato University, Tokyo, Japan; ${ }^{2}$ Graduate School of Infection Control Sciences, Kitasato University, Tokyo, Japan and ${ }^{3}$ Kitasato Institute for Life Sciences, Kitasato University, Tokyo, Japan

Correspondence: Dr T Nakashima, Research Organization for Infection Control Sciences, Kitasato University and Yōko Takahashi, Kitasato Institute for Life Sciences, Kitasato University, 5-9-1 Shirokane, Minato-ku, Tokyo 108-8641, Japan.

E-mail: takuji@lisci.kitasato-u.ac.jp or ytakaha@lisci.kitasato-u.ac.jp

Received 19 December 2013; revised 20 February 2013; accepted 9 March 2014; published online 2 April 2014 


\section{RESULTS AND DISCUSSION}

\section{Improvement of fermentation}

We previously reported that mangromicins A (1) and B (2) were isolated from the cultured broth of L. aerocolonigenes K10-0216 using a production medium consisting of $2 \%$ soluble starch, $0.5 \%$ glycerol, $1.0 \%$ de-fatted wheat germ, $0.3 \%$ meat extract, $0.3 \%$ dry yeast and $0.3 \% \mathrm{CaCO}_{3}$ (basal medium). However, the yields of both $\mathbf{1}$ and 2 were $0.24 \mu \mathrm{g} \mathrm{ml}^{-1}$ in the basal medium (Supplementary Figure S1). Therefore, we improved the production medium to increase the productivity of both $\mathbf{1}$ and 2 . The productivity of $\mathbf{1}$ and $\mathbf{2}$ were examined by altering the amount of all components in the basal medium. The composition of the modified medium was fixed at $5 \%$ soluble starch, $0.5 \%$ glycerol, $1.0 \%$ de-fatted wheat germ, $1.0 \%$ dry yeast and $0.3 \% \mathrm{CaCO}_{3}$. The productivity of 1 and 2 in the modified medium was increased 100-fold compared with the original medium (Supplementary Figure S1). In addition, many new analogs were detected by LC/UV and LC/MS which were subsequently isolated and their chemical structures were elucidated.

\section{Isolation of six new mangromicin analogs}

The procedure for isolation of $\mathbf{1 - 8}$ is summarized in Scheme 1. Isolation of all mangromicin analogs was guided by $\mathrm{PC}$ properties using LC/UV and LC/MS equipment. The above-described modified medium was used for production of mangromicin analogs. The 8-day-old culture broth (101) was centrifuged to separate mycelium

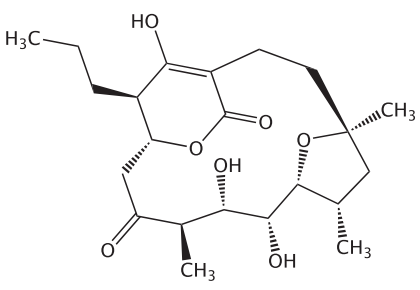

Mangromicin A (1)

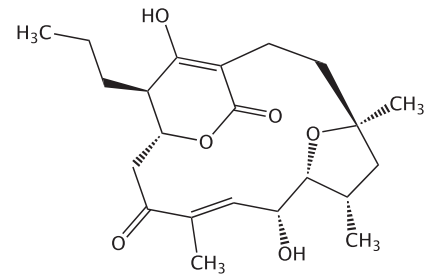

Mangromicin B (2)
Figure 1 Structures of mangromicins A (1) and B (2).

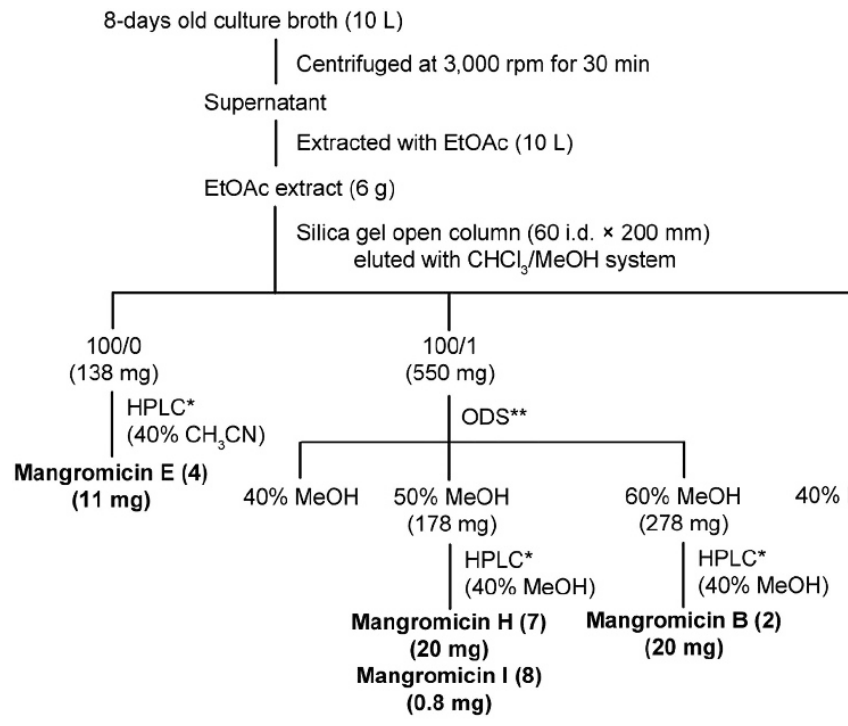

8-days old culture broth ( $10 \mathrm{~L})$

Supernatant

EtOAc extract $(6 \mathrm{~g})$

*prep. HPLC (Inertsil ODS-4, 10 i.d. $\times 250$ mm, $4.7 \mathrm{~mL} / \mathrm{min}$, UV $254 \mathrm{~nm}$ )

** ODS open column (40 i.d. $\times 150 \mathrm{~mm}$ ) eluted with $\mathrm{MeOH} / \mathrm{H}_{2} \mathrm{O}$ or $\mathrm{CH}_{3} \mathrm{CN} / \mathrm{H}_{2} \mathrm{O}$ system and supernatant. The supernatant was extracted three times with ethyl acetate (101). The organic layer was concentrated to dryness in vacuo to afford a crude material $(6 \mathrm{~g})$. The ethyl acetate extract was applied to silica gel column chromatography FL100D (60 i.d. $\times 200 \mathrm{~mm}$, Fuji Silysia Co., Tokyo, Japan), which was eluted with each 11 of a mixture of $\mathrm{CHCl}_{3}-\mathrm{MeOH}(100: 0,100: 1,50: 1$ and 10:1) in that order. The $\mathrm{CHCl}_{3}-\mathrm{MeOH}$ (100:0) fraction (138 mg) was dissolved in a small amount of $\mathrm{MeOH}$ and purified by HPLC on an Inertsil ODS-4 column (10 i.d. $\times 250 \mathrm{~mm}$ ) with $40 \% \mathrm{MeCN}$ at $4.7 \mathrm{ml} \mathrm{min}^{-1}$ (monitoring at UV $254 \mathrm{~nm}$ ). The yield of mangromicin E (4) was $11 \mathrm{mg}$. The $\mathrm{CHCl}_{3}-\mathrm{MeOH}(100: 1)$ fraction $(550 \mathrm{mg}$ ) was applied on an ODS column (40 i.d. $\times 150 \mathrm{~mm}$, Senshu Scientific Co., Tokyo, Japan). After washing with $40 \% \mathrm{MeOH}$, the fractions containing mangromicins $\mathrm{H} \mathrm{(7)}$ and I (8) were eluted with 50\% $\mathrm{MeOH}$, followed by concentration in vacuo. This fraction $(178 \mathrm{mg}$ ) was dissolved in a small amount of $\mathrm{MeOH}$ and purified by HPLC on an Inertsil ODS-4 column (10 i.d. $\times 250 \mathrm{~mm}$ ) with $40 \% \mathrm{MeOH}$ at $4.7 \mathrm{mlmin}^{-1}$ (monitoring at UV $254 \mathrm{~nm}$ ). The yields of mangromicins $\mathrm{H}$ (7) and I (8) were 20 and $0.8 \mathrm{mg}$, respectively. The same ODS-treated fraction containing mangromicin B (2) was eluted with $60 \% \mathrm{MeOH}$, followed by concentration in vacuo. Next, the same ODS-treated fractions containing mangromicin B (2) was eluted with $60 \% \mathrm{MeOH}$, followed by concentration in vacuo. This fraction $(278 \mathrm{mg})$ was dissolved in a small amount of $\mathrm{MeOH}$ and purified by HPLC on an Inertsil ODS-4 column (10 i.d. $\times 250 \mathrm{~mm}$ ) with $40 \% \mathrm{MeOH}$ at $4.7 \mathrm{ml} \mathrm{min}^{-1}$ (monitoring at UV $254 \mathrm{~nm}$ ). The yield of mangromicin B (2) was $20 \mathrm{mg}$. The $\mathrm{CHCl}_{3}-\mathrm{MeOH}$ (50:1) fraction (510 mg) was applied on an ODS column (40 i.d. $\times 150 \mathrm{~mm}$, Senshu Scientific Co.). After washing with $40 \% \mathrm{MeOH}$, the fractions containing mangromicins A (1) and D (3) were eluted with 50\% $\mathrm{MeOH}$, and then concentrated in vacuo. This fraction $(211 \mathrm{mg})$ was dissolved in a small amount of $\mathrm{MeOH}$ and purified by HPLC on an Inertsil ODS-4 column (10 i.d. $\times 250 \mathrm{~mm}$ ) with $15 \% \mathrm{MeOH}$ at $4.7 \mathrm{ml} \mathrm{min}^{-1}$ (monitoring at UV $254 \mathrm{~nm}$ ). The yields of mangromicins A (1) and D (3) were 35 and $60 \mathrm{mg}$, respectively. The $\mathrm{CHCl}_{3}-\mathrm{MeOH}$ (10:1) fraction $(650 \mathrm{mg})$ was applied on an ODS column (40 i.d. $\times$ $150 \mathrm{~mm}$ ). After washing with $40 \% \mathrm{MeOH}$, the fractions containing 
mangromicins F (5) and G (6) were eluted with 50\% $\mathrm{MeOH}$, followed concentration in vacuo. This fraction $(190 \mathrm{mg})$ was dissolved in a small amount of $\mathrm{MeOH}$ and purified by HPLC on an Inertsil ODS -4 column $\left(10\right.$ i.d. $\times 250 \mathrm{~mm}$ ) with $15 \% \mathrm{MeOH}$ at $4.7 \mathrm{ml} \mathrm{min}^{-1}$ (monitoring at UV $254 \mathrm{~nm}$ ). The yields of mangromicins F (5) and $\mathrm{G}$ (6) were 20 and $9 \mathrm{mg}$, respectively.

\section{PC properties of six new mangromicin analogs}

The PC properties of compounds $\mathbf{3 - \mathbf { 8 }}$ are summarized in Table $\mathbf{1}$. All analogs are readily soluble in $\mathrm{MeOH}, \mathrm{EtOH}$ and $\mathrm{MeCN}$. Compounds 3-8 showed absorption maxima at 231-251 nm in UV spectra. The IR absorption at $3421-3451$ and $1651-1655 \mathrm{~cm}^{-1}$ in 3-8 suggested the presence of hydroxyl and carbonyl groups. The PC properties are similar for not only these six compounds but also for mangromicins A (1) and B (2), confirming that these compounds are structurally related.

\section{Structure elucidation of mangromicin $\mathbf{H}$ (7)}

Structure analysis was initially performed using mangromicin $\mathrm{H}$ (7) as it had the lowest MW among the analogs. Mangromicin H (7) was obtained as a pale yellow powder determined to have the molecular formula of $\mathrm{C}_{21} \mathrm{H}_{32} \mathrm{O}_{6}$ by HRESIMS $[\mathrm{M}+\mathrm{H}]^{+} \mathrm{m} / z 381.2277$ (calcd for $\mathrm{C}_{21} \mathrm{H}_{33} \mathrm{O}_{6}, 381.2272$ ). The $1 \mathrm{D}$ and $2 \mathrm{D}$ NMR spectra of 7 were measured in $\mathrm{CD}_{3} \mathrm{OD}$.

The ${ }^{1} \mathrm{H}$ and ${ }^{13} \mathrm{C}$ NMR spectral data of 7 are listed in Tables 2 and 3, respectively. The ${ }^{1} \mathrm{H}$ NMR data indicated the presence of three oxygenated $s p^{3}$ methines, three $s p^{3}$ methines containing two methines coupled to methyl groups, six methylenes, one primary methyl, two secondary methyls and one tertiary methyl. The ${ }^{13} \mathrm{C}$ NMR spectrum showed the resonances of 21 carbons, which were classified into two olefinic carbons $\left(\delta_{\mathrm{c}} 102.8\right.$ and 169.3$)$, two carbonyl carbons $\left(\delta_{\mathrm{c}} 169.6\right.$ and 212.8), one oxygenated $s p^{3}$ quaternary carbon $\left(\delta_{c} 83.8\right)$, three oxygenated $s p^{3}$ methine carbons $\left(\delta_{\mathrm{c}} 73.7,69.2\right.$ and 82.0), three $s p^{3}$ methine carbons $\left(\delta_{\mathrm{c}} 46.1,49.3\right.$ and 37.0$)$, six $s p^{3}$ methylene carbons $\left(\delta_{c} 44.3,37.7,49.4,36.5,19.5\right.$ and 25.8$)$ and four methyl carbons $\left(\delta_{\mathrm{c}} 11.9,15.5,15.5\right.$ and 25.3$)$ by HSQC spectra. The ${ }^{1} \mathrm{H}-{ }^{1} \mathrm{H}$ COSY and HOHAHA spectra revealed four partial structures: (a) C-5/C-6, (b) C-8/C-13, C-8/C-8-Me and C-12/C-12-Me, (c) C-15/C-16, (d) $\mathrm{C}-4 / \mathrm{C}-2^{\prime}-\mathrm{Me}$, as shown in Figure 2. The presence of a 5,6dihydro-4-hydroxy-2-pyrone moiety was confirmed by the HMBC correlations from $\mathrm{H}_{3}-2^{\prime}$-Me to $\mathrm{C}-4$; from $\mathrm{H}_{2}-1^{\prime}$ to $\mathrm{C}-3$, C-4 and $\mathrm{C}-5$; from $\mathrm{H}-4$ to $\mathrm{C}-\mathrm{1}^{\prime}$ and $\mathrm{C}-2^{\prime}-\mathrm{Me}$; from $\mathrm{H}-5$ to $\mathrm{C}-3, \mathrm{C}-4, \mathrm{C}-6$ and $\mathrm{C}-\mathrm{1}^{\prime}$; from $\mathrm{H}-16$ to $\mathrm{C}-1, \mathrm{C}-2$ and $\mathrm{C}-3$. A tetrahydrofurane unit with a secondary methyl and a tertiary methyl linked to C-12 and C-14 positions was confirmed by the HMBC correlations from $\mathrm{H}-12$ to C-14; from $\mathrm{H}_{2}-13$ to $\mathrm{C}-11$; from $\mathrm{H}_{3}-12-\mathrm{Me}$ to $\mathrm{C}-11, \mathrm{C}-12$ and $\mathrm{C}-13$; from $\mathrm{H}_{3}-14-\mathrm{Me}$ to $\mathrm{C}-13$ and $\mathrm{C}-14$. The $\mathrm{HMBC}$ correlations from $\mathrm{H}_{3}$-14-Me to C-15; from $\mathrm{H}_{2}-15$ to C-14, C-14-Me and C-16; from $\mathrm{H}_{2}-16$ to $\mathrm{C}-14$, and $\mathrm{C}-15$ showed that a 5,6-dihydro-4-hydroxy-2pyrone moiety and tetrahydrofurane unit were connected by an ethylene bond. Finally, the HMBC correlations from H-6 to C-5 and C-7; from $\mathrm{H}_{3}-8$-Me to $\mathrm{C}-7$ revealed the connectivity between C-6 and C-8 via ketone carbon at C-7, which connected two partial structures $\mathrm{a}$ and $\mathrm{b}$. Therefore, the planar structure of $\mathbf{7}$ was elucidated as shown in Figure 2a, and it was designated as mangromicin H, 4-de- $n$-propyl4-ethyl-9-dehydroxy analog of mangromicin A (1).

The relative configuration of 7 was estimated by ${ }^{1} \mathrm{H}-{ }^{1} \mathrm{H}$ coupling constant analysis and ROESY experiments (Figure $2 \mathrm{~b}$ ). The ROESY correlations were observed between $\mathrm{H}_{2}-13 \mathrm{~b} / \mathrm{H}_{3}-12-\mathrm{Me}$ and $\mathrm{H}_{2}-13 \mathrm{~b} /$ $\mathrm{H}_{3}$-14-Me. These results indicated that $\mathrm{H}_{3}-14-\mathrm{Me}$ and $\mathrm{H}_{3}-12-\mathrm{Me}$ are located on the identical surface of the tetrahydrofurane unit. Moreover, the ROESY correlations were observed between $\mathrm{H}_{3}-8-\mathrm{Me} / \mathrm{H}-10$ and $\mathrm{H}-10 / \mathrm{H}_{3}-12-\mathrm{Me}$. In addition, J-coupling between $\mathrm{H}_{\alpha 1}$ and $\mathrm{H}_{\beta 1}$ was almost zero, and between $\mathrm{H}_{\alpha 2}$ and $\mathrm{H}_{\beta 2}$ was a small coupling constant $(0.8 \mathrm{~Hz})$. Therefore, the relative configuration from $\mathrm{C}-8$ to $\mathrm{C}-14$ in 7 was determined as shown in Figure 2b. ROESY and NOE correlations were observed between $\mathrm{H}-4$ and H-6a and between H-4 and $\mathrm{H}-5$. No coupling constants were observed between $\mathrm{H}-4 / \mathrm{H}-5$ and $\mathrm{H}-5 / \mathrm{H}-6 \mathrm{a}$. These results reveal that the $n$-ethyl group at C-4 and methylene at C-6 bound to 5,6-dihydro-4-hydroxy-2-pyrone moiety are located on the opposite surface. Therefore, it was suggested that 7 has the relative configuration of $4 R^{\star}, 5 R^{\star}, 8 R^{\star}, 9 S^{\star}, 10 R^{\star}, 11 R^{\star}, 12 S^{\star}$ and $14 S^{*}$ (Figure $2 \mathrm{~b}$ ).

\section{Structure elucidation of mangromicin D (3)}

Mangromicin D (3) was obtained as a pale yellow powder determined to have the molecular formula of $\mathrm{C}_{22} \mathrm{H}_{34} \mathrm{O}_{7}$ by HRESIMS $[\mathrm{M}+\mathrm{H}]^{+}$ $m / z 411.2383$ (calcd for $\mathrm{C}_{22} \mathrm{H}_{35} \mathrm{O}_{7}, 411.2392$ ). As some broadened signals were observed in $\mathrm{CD}_{3} \mathrm{OD}$, the $1 \mathrm{D}$ and $2 \mathrm{D}$ spectra of 3 in $\mathrm{DMSO}$ (dimethylsulphoxide) $-d_{6}$ were also measured at $80^{\circ} \mathrm{C}$ to yield sharper signals.

Table 1 PC properties of mangromicin analogs

\begin{tabular}{|c|c|c|c|c|c|c|}
\hline & \multicolumn{6}{|c|}{ Mangromicin } \\
\hline & $D(3)$ & $E(4)$ & $F(5)$ & $G(6)$ & $H(7)$ & I(8) \\
\hline Appearance & Pale yellow & Pale yellow & Pale yellow & Pale yellow & Pale yellow & Pale yellow \\
\hline Molecular formula & $\mathrm{C}_{22} \mathrm{H}_{34} \mathrm{O}_{7}$ & $\mathrm{C}_{22} \mathrm{H}_{32} \mathrm{O}_{6}$ & $\mathrm{C}_{21} \mathrm{H}_{32} \mathrm{O}_{7}$ & $\mathrm{C}_{22} \mathrm{H}_{34} \mathrm{O}_{7}$ & $\mathrm{C}_{21} \mathrm{H}_{32} \mathrm{O}_{6}$ & $\mathrm{C}_{22} \mathrm{H}_{32} \mathrm{O}_{7}$ \\
\hline MW & 410.5012 & 392.4859 & 396.4746 & 410.5012 & 380.4752 & 408.4853 \\
\hline \multicolumn{7}{|l|}{$E S I-M S(m / z)$} \\
\hline Calcd & 411.2392 & 393.2277 & 397.2218 & 411.2375 & 381.2272 & 409.2222 \\
\hline Found & 411.2383 & 393.2277 & 397.2226 & 411.2385 & 381.2277 & 409.2226 \\
\hline$[\alpha]_{D}^{25.3}(c 0.1, \mathrm{MeOH})$ & +27.96 & +30.48 & +51.56 & +29.16 & +33.80 & NT \\
\hline UV $\lambda_{\max }{ }^{\mathrm{MeOH}} \mathrm{nm}(\varepsilon)$ & $251(1806)$ & $231(314)$ & $250(1387)$ & $251(1231)$ & $251(1521)$ & $246(490)$ \\
\hline $\mathrm{IR} v_{\max }{ }^{\mathrm{KBr}} \mathrm{cm}^{-1}$ & 3421,1655 & 3451,1651 & 3433,1651 & 3425,1651 & 3430,1651 & 3431,1651 \\
\hline \multirow[t]{2}{*}{ Soluble in } & $\mathrm{MeOH}$ & $\mathrm{MeOH}$ & $\mathrm{MeOH}$ & $\mathrm{MeOH}$ & $\mathrm{MeOH}$ & $\mathrm{MeOH}$ \\
\hline & $\mathrm{EtOH} \mathrm{MeCN}$ & $\mathrm{EtOH} \mathrm{MeCN}$ & EtOH MeCN & EtOH MeCN & EtOH MeCN & EtOH MeCN \\
\hline
\end{tabular}

Abbreviation: NT, not tested. 
Table $2{ }^{1} \mathrm{H}$ NMR data for mangromicin analogs

\begin{tabular}{|c|c|c|c|c|c|c|}
\hline Position & $\begin{array}{c}\boldsymbol{D}(3)^{\mathrm{a}} \\
\delta_{H}, \text { mult }(\mathrm{J} \text { in } H z)\end{array}$ & $\begin{array}{c}E(4)^{\mathrm{b}} \\
\delta_{H}, \text { mult }(\mathrm{J} \text { in } \mathrm{Hz})\end{array}$ & $\begin{array}{c}\boldsymbol{F}(5)^{\mathrm{b}} \\
\delta_{H}, \text { mult }(\mathrm{J} \text { in } \mathrm{Hz})\end{array}$ & $\begin{array}{c}G(6)^{\mathrm{b}} \\
\delta_{H}, \text { mult }(\mathrm{J} \text { in } \mathrm{Hz})\end{array}$ & $\begin{array}{c}\boldsymbol{H}(7)^{\mathrm{b}} \\
\delta_{H}, \text { mult }(\mathrm{J} \text { in } \mathrm{Hz})\end{array}$ & $\delta_{H}, I^{(8)^{\mathrm{b}}}$ \\
\hline 2 & & $4.63 \mathrm{dd}(2.0,9.6)$ & & & & \\
\hline 5 & $4.56 \mathrm{~d}(8.4)$ & $\begin{array}{c}4.94 \text { ddd }(6.0,12.0 \\
12.6)\end{array}$ & $4.83 \mathrm{~m}$ & $4.73 \mathrm{dd}(1.6,11.8)$ & $4.79 \mathrm{~d}(12.0)$ & $4.93 \mathrm{dd}(0.8,11.2)$ \\
\hline $6 a$ & $2.33 \mathrm{~m}$ & $2.51 \mathrm{~m}$ & $2.38 \mathrm{~m}$ & $2.15 \mathrm{dd}(17.4,1.6)$ & $2.36 \mathrm{~d}(18.4)$ & $2.40 \mathrm{~m}$ \\
\hline 8 & $2.96 \mathrm{~m}$ & & $3.33 \mathrm{~m}$ & $2.72 \mathrm{~m}$ & $2.72 \mathrm{~m}$ & \\
\hline $9 a$ & $1.68 \mathrm{~m}$ & $6.67 \mathrm{~d}(8.8)$ & $1.61 \mathrm{~m}$ & $1.90 \mathrm{~m}$ & $1.76 \mathrm{~m}$ & $4.20 \mathrm{~d}(8.4)$ \\
\hline $9 b$ & $1.84 \mathrm{~m}$ & & $1.80 \mathrm{~m}$ & $2.32 \mathrm{~m}$ & $2.42 \mathrm{~m}$ & \\
\hline 10 & $3.50 \mathrm{~m}$ & $4.70 \mathrm{~d}(8.8)$ & $3.65 \mathrm{~m}$ & 3.58 ddd $(10.4,3.6,0.4)$ & 3.57 ddd $(0.8,3.2,5.6)$ & $3.20 \mathrm{~d}(8.4)$ \\
\hline 11 & $3.38 \mathrm{dd}(2.0,7.2)$ & $3.60 \mathrm{~m}$ & $3.55 \mathrm{~m}$ & $3.33 \mathrm{~m}$ & $3.40 \mathrm{~m}$ & $3.42 \mathrm{~d}(8.8)$ \\
\hline $16 a$ & $1.93 \mathrm{dd}(4.8,9.8)$ & $1.67 \mathrm{~m}$ & $2.06 \mathrm{~m}$ & $2.05 \mathrm{dt}(4.0,7.2)$ & $2.04 \mathrm{~m}$ & $2.11 \mathrm{~m}$ \\
\hline $16 \mathrm{~b}$ & $2.71 \mathrm{~m}$ & $2.45 \mathrm{~m}$ & $\begin{array}{c}2.85 \text { ddd }(4.4,13.6, \\
15.4)\end{array}$ & $2.73 \mathrm{~m}$ & $\begin{array}{c}2.88 \text { ddd }(4.0,10.4, \\
12.0)\end{array}$ & $\begin{array}{c}2.90 \text { ddd }(3.8,13.2 \\
14.6)\end{array}$ \\
\hline $1^{\prime}$ & $1.48 \mathrm{~s}$ & $1.32 \mathrm{~m}, 1.97 \mathrm{~m}$ & $1.65 \mathrm{~m}$ & $1.61 \mathrm{~m}, 1.57 \mathrm{~m}$ & $1.64 \mathrm{~m}, 1.70 \mathrm{~m}$ & $1.68 \mathrm{~m}, 1.72 \mathrm{~m}$ \\
\hline $2^{\prime}$ & $1.30 \mathrm{~m}, 1.44 \mathrm{~m}$ & $1.38 \mathrm{~m}, 1.48 \mathrm{~m}$ & & $1.38 \mathrm{~m}, 1.53 \mathrm{~m}$ & & \\
\hline $2^{\prime}-(\mathrm{Me})$ & & & $1.03 \mathrm{t}(7.4)$ & & $1.03 \mathrm{t}(8.0)$ & $1.05 \mathrm{t}(7.6)$ \\
\hline $3^{\prime}-(\mathrm{Me})$ & 0.88 t (6.4) & $0.98 \mathrm{t}(7.2)$ & & $0.96 \mathrm{t}(12.8)$ & & \\
\hline $8-\mathrm{CH}_{2}$ & $3.30 \mathrm{~m}, 3.50 \mathrm{~m}$ & & $3.52 \mathrm{~m}, 3.67 \mathrm{~m}$ & & & $5.68 d(2.0), 6.48 d(2.0)$ \\
\hline 8-Me & & $1.79 \mathrm{~d}(1.2)$ & & $1.03(3 \mathrm{H}, \mathrm{d}, 13.7)$ & $1.06 \mathrm{~d}(5.6)$ & \\
\hline 9-OMe & & & & & & $3.24 \mathrm{~s}$ \\
\hline
\end{tabular}

aln DMSO- $d_{6}\left(80^{\circ} \mathrm{C}\right)$.

bIn $\mathrm{CH}_{3} \mathrm{OD}$.

From a comparison of the ${ }^{1} \mathrm{H}$ and ${ }^{13} \mathrm{C}$ NMR of 3 and 7, the signals of a $n$-propyl $\left(1^{\prime} ; \delta_{\mathrm{H}} 1.48 / \delta_{\mathrm{C}} 32.9,2^{\prime} ; \delta_{\mathrm{H}} 1.30\right.$ and $1.44 / \delta_{\mathrm{C}} 19.1,3^{\prime}$; $\left.\delta_{\mathrm{H}} 0.88 / \delta_{\mathrm{C}} 13.3\right)$ and hydroxymethyl $\left(8-\mathrm{CH}_{2} ; \delta_{\mathrm{H}} 3.30\right.$ and $3.50 / \delta_{\mathrm{C}}$ $62.3)$ groups were observed in 3 instead of those of an ethyl $\left(1^{\prime} ; \delta_{\mathrm{H}}\right.$ 1.64 and $\left.1.70 / \delta_{\mathrm{C}} 25.8,2^{\prime} ; \delta_{\mathrm{H}} 1.03 / \delta_{\mathrm{C}} 11.9\right)$ together with a secondary methyl $\left(8-\mathrm{Me} ; \delta_{\mathrm{H}} 1.06 / \delta_{\mathrm{C}} 15.5\right)$ in 7 . In the COSY correlations and HMBC correlations, the conectivity of the $n$-propyl group at C-4 (from $\mathrm{H}_{2}-1^{\prime}$ to $\mathrm{C}-4$, from $\mathrm{H}_{2}-2^{\prime}$ to $\mathrm{C}-4$ and from $\mathrm{H}-4$ to $\mathrm{C}-1^{\prime}$ and $\mathrm{C}-2^{\prime}$ ) and a hydroxymethyl group at C-8 (from $\mathrm{H}_{2}-8$ to C-7 and C-9, and from $\mathrm{H}-9$ to $\mathrm{CH}_{2}-8$ ) in 3 was confirmed (Supplementary Figure S2). In addition, the presence of an enol-type hydroxy group at C-3 was detected by the HMBC correlations from 3-OH $\left(\delta_{\mathrm{H}}\right.$ br. $9.55-9.83$ in DMSO- $d_{6}$, Supplementary Figure S7) to C-2 and C-4. Therefore, the planar structure of $\mathbf{3}$ was elucidated as shown in Figure 3, and it was designated as mangromicin D, a 8-oxymethylene-9-dehydroxy analog of mangromicin A (1).

\section{Structure elucidation of mangromicin E (4)}

Mangromicin E (4) was obtained as a pale yellow powder determined to have the molecular formula of $\mathrm{C}_{22} \mathrm{H}_{32} \mathrm{O}_{6}$ by HRESIMS $[\mathrm{M}+\mathrm{H}]^{+}$ $m / z$ 393.2277 (calcd for $\mathrm{C}_{22} \mathrm{H}_{33} \mathrm{O}_{6}, 393.2277$ ). The 1D and 2D NMR spectra of 4 were obtained in $\mathrm{CD}_{3} \mathrm{OD}$.
From a comparison of the ${ }^{1} \mathrm{H}$ and ${ }^{13} \mathrm{C}$ NMR of 4 and 7 , the signals of one $s p^{3}$ methine $\left(2-\mathrm{CH} ; \delta_{\mathrm{H}} 4.63 / \delta_{\mathrm{C}} 55.2\right)$, one carbonyl carbon $\left(\mathrm{C}-2 ; \delta_{\mathrm{c}} 203.6\right)$, two olefinic carbons $\left(\mathrm{C}-8 ; \delta_{\mathrm{c}} 136.7\right.$ and C-9; 148.0), one $s p^{2}$ methine $\left(9-\mathrm{CH} ; \delta_{\mathrm{H}} 6.71\right)$ and a $n$-propyl $\left(1^{\prime} ; \delta_{\mathrm{H}} 1.32\right.$ and $1.97 / \delta_{\mathrm{C}} 28.5,2^{\prime} ; \delta_{\mathrm{H}} 1.38$ and $\left.1.48 / \delta_{\mathrm{C}} 21.1,3^{\prime} ; \delta_{\mathrm{H}} 0.98 / \delta_{\mathrm{C}} 14.3\right)$ group were observed in 4 instead of those of two olefinic carbons (C-2 and C-3; $\delta_{\mathrm{c}} 102.8$ and 169.3), a methine $\left(8-\mathrm{CH} ; \delta_{\mathrm{H}} 2.72 / \delta_{\mathrm{C}} 49.3\right)$, a methylene $\left(\mathrm{H}_{2}-9 ; \delta_{\mathrm{H}} 1.76\right.$ and 37.7$)$ and an ethyl $\left(1^{\prime} ; \delta_{\mathrm{H}} 1.64\right.$ and $\left.1.70 / \delta_{\mathrm{C}} 25.8,2^{\prime} ; \delta_{\mathrm{H}} 1.03 / \delta_{\mathrm{C}} 11.9\right)$ group in 7 . In the COSY correlations and $\mathrm{HMBC}$ correlations, the conectivity of the $n$-propyl group at C-4 (from $\mathrm{H}_{2}-1^{\prime}$ to $\mathrm{C}-3, \mathrm{C}-4$ and $\mathrm{C}-5$, from $\mathrm{H}_{2}-2^{\prime}$ to $\mathrm{C}-4$ and from $\mathrm{H}-4$ to $\mathrm{C}-1^{\prime}$ and $\mathrm{C}-2^{\prime}$ ) in 4 was confirmed (Supplementary Figure S2). Therefore, the planar structure of $\mathbf{4}$ was elucidated as shown in Figure 3, and it was designated as mangromicin E, a 3-keto analog of mangromicin B (2). It is likely that akaerolide and mangromicin $\mathrm{E}$ are in relationship of stereoisomers. ${ }^{13}$

\section{Structure elucidation of mangromicin F (5)}

Mangromicin F (5) was obtained as a pale yellow powder determined to have the molecular formula of $\mathrm{C}_{21} \mathrm{H}_{32} \mathrm{O}_{7}$ by HRESIMS $[\mathrm{M}+\mathrm{H}]^{+}$ $m / z 397.2226$ (calcd for $\mathrm{C}_{21} \mathrm{H}_{33} \mathrm{O}_{7}, 397.2218$ ). The $1 \mathrm{D}$ and 2D NMR spectra of 5 were obtained in $\mathrm{CD}_{3} \mathrm{OD}$. 
Table $3{ }^{13} \mathrm{C}$ NMR data for mangromicin analogs

\begin{tabular}{|c|c|c|c|c|c|c|}
\hline Position & $\begin{array}{c}D(3)^{\mathrm{a}} \\
\delta_{C}, \text { mult }\end{array}$ & $\begin{array}{c}E(4)^{\mathrm{b}} \\
\delta_{C}, \text { mult }\end{array}$ & $\begin{array}{c}F(5)^{\mathrm{b}} \\
\delta_{C}, \text { mult }\end{array}$ & $\begin{array}{c}G(6)^{\mathrm{b}} \\
\delta_{C}, \text { mult }\end{array}$ & $\begin{array}{c}H(7)^{\mathrm{b}} \\
\delta_{C}, \text { mult }\end{array}$ & $\begin{array}{c}\text { I (8) } \\
\delta_{C}, \text { mult }\end{array}$ \\
\hline & 164.4 C & $172.2 \mathrm{C}$ & $169.2 \mathrm{C}$ & $169.0 \mathrm{C}$ & $169.6 \mathrm{C}$ & $168.3 \mathrm{C}$ \\
\hline 2 & $101.8 \mathrm{C}$ & $55.2 \mathrm{CH}$ & $103.3 \mathrm{C}$ & $103.0 \mathrm{C}$ & $102.8 \mathrm{C}$ & $103.4 \mathrm{C}$ \\
\hline 3 & $163.6 \mathrm{C}$ & $204.3 \mathrm{C}$ & $167.5 \mathrm{C}$ & $167.9 \mathrm{C}$ & $169.3 \mathrm{C}$ & $169.3 \mathrm{C}$ \\
\hline & $41.4 \mathrm{CH}$ & $50.9 \mathrm{CH}$ & $45.4 \mathrm{CH}$ & $44.2 \mathrm{CH}$ & $46.1 \mathrm{CH}$ & $45.6 \mathrm{CH}$ \\
\hline 5 & $2 \mathrm{CH}$ & $77.8 \mathrm{CH}$ & $73.6 \mathrm{CH}$ & $73.9 \mathrm{CH}$ & $3.7 \mathrm{CH}$ & $3.8 \mathrm{CH}$ \\
\hline 6 & $45.5 \mathrm{CH}_{2}$ & $38.4 \mathrm{CH}_{2}$ & $46.6 \mathrm{CH}_{2}$ & $44.0 \mathrm{CH}_{2}$ & $44.3 \mathrm{CH}_{2}$ & $44.0 \mathrm{CH}_{2}$ \\
\hline 7 & 210.1 C & 203.6 C & 213.7 C & 212.4 C & 212.8 C & 197.7 C \\
\hline & $9.2 \mathrm{CH}$ & 136.7 C & $49.9 \mathrm{CH}$ & $43.6 \mathrm{CH}$ & $49.3 \mathrm{CH}$ & $147.5 \mathrm{C}$ \\
\hline$y$ & $\mathrm{CH}_{2}$ & $148.0 \mathrm{CH}$ & $35.1 \mathrm{CH}_{2}$ & $38.6 \mathrm{CH}_{2}$ & $37.7 \mathrm{CH}_{2}$ & $2.3 \mathrm{CH}$ \\
\hline 10 & $6.3 \mathrm{CH}$ & 69.1 & $68.9 \mathrm{CH}$ & & & $9.5 \mathrm{CH}$ \\
\hline 11 & $.2 \mathrm{CH}$ & $\mathrm{H}$ & $84.6 \mathrm{CH}$ & $82.1 \mathrm{CH}$ & $82.0 \mathrm{CH}$ & $80.1 \mathrm{CH}$ \\
\hline 2 & 3 & 3 & $7.2 \mathrm{CH}$ & 36.9 & 37.0 & $7.5 \mathrm{CH}$ \\
\hline 13 & $47.9 \mathrm{CH}_{2}$ & $50.5 \mathrm{CH}_{2}$ & $49.7 \mathrm{CH}_{2}$ & $41.8 \mathrm{CH}_{2}$ & $49.4 \mathrm{CH}_{2}$ & $48.0 \mathrm{CH}_{2}$ \\
\hline 14 & $1.2 \mathrm{C}$ & $83.5 \mathrm{C}$ & 83.2 C & 87.0 C & 83.8 C & 85.0 C \\
\hline 15 & $.4 \mathrm{CH}_{2}$ & $33.2 \mathrm{CH}_{2}$ & $36.0 \mathrm{CH}_{2}$ & $34.2 \mathrm{CH}_{2}$ & $36.5 \mathrm{CH}_{2}$ & $37.3 \mathrm{CH}_{2}$ \\
\hline 16 & $3.1 \mathrm{CH}_{2}$ & $21.4 \mathrm{CH}_{2}$ & $19.5 \mathrm{CH}_{2}$ & $18.9 \mathrm{CH}_{2}$ & $19.5 \mathrm{CH}_{2}$ & $19.4 \mathrm{CH}_{2}$ \\
\hline $1^{\prime}$ & $32.9 \mathrm{CH}_{2}$ & $28.5 \mathrm{CH}_{2}$ & $24.8 \mathrm{CH}_{2}$ & $34.2 \mathrm{CH}_{2}$ & $25.8 \mathrm{CH}_{2}$ & $25.7 \mathrm{CH}_{2}$ \\
\hline $2^{\prime}$ & $19.1 \mathrm{CH}_{2}$ & $21.1 \mathrm{CH}_{2}$ & $21.1 \mathrm{CH}_{2}$ & $21.3 \mathrm{CH}_{2}$ & & \\
\hline $2^{\prime}-\mathrm{Me}$ & & & & & $11.9 \mathrm{CH}_{3}$ & $11.8 \mathrm{CH}_{3}$ \\
\hline $3^{\prime}-\mathrm{Me}$ & $13.3 \mathrm{CH}_{3}$ & $14.3 \mathrm{CH}_{3}$ & $14.3 \mathrm{CH}_{3}$ & $14.2 \mathrm{CH}_{3}$ & & \\
\hline 8- $\mathrm{CH}_{2}$ & $62.3 \mathrm{CH}_{2}$ & & & & & $126.6 \mathrm{CH}_{2}$ \\
\hline 8-Me & & $11.8 \mathrm{CH}_{3}$ & $11.8 \mathrm{CH}_{3}$ & $15.3 \mathrm{CH}_{3}$ & $15.5 \mathrm{CH}_{3}$ & \\
\hline 9-OMe & & & & & & $57.0 \mathrm{CH}_{3}$ \\
\hline 12-Me & $14.6 \mathrm{CH}_{3}$ & $18.8 \mathrm{CH}_{3}$ & $18.7 \mathrm{CH}_{3}$ & $13.7 \mathrm{CH}_{3}$ & $15.5 \mathrm{CH}_{3}$ & $13.7 \mathrm{CH}_{3}$ \\
\hline $14-\mathrm{CH}_{2}$ & & & & $65.9 \mathrm{CH}_{2}$ & & \\
\hline 14-Me & $24.0 \mathrm{CH}_{3}$ & $25.5 \mathrm{CH}_{3}$ & $25.5 \mathrm{CH}_{3}$ & & $25.3 \mathrm{CH}_{3}$ & $24.5 \mathrm{CH}_{3}$ \\
\hline
\end{tabular}

an DMSO- $d_{6}\left(80^{\circ} \mathrm{C}\right)$

bIn $\mathrm{CH}_{3} \mathrm{OD}$.

From a comparison of the ${ }^{1} \mathrm{H}$ and ${ }^{13} \mathrm{C}$ NMR of 5 and 7, the signals of a hydroxymethyl $\left(8-\mathrm{CH}_{2} ; \delta_{\mathrm{H}} 3.52\right.$ and $\left.3.67 / \delta_{\mathrm{C}} 64.8\right)$ group were observed in 5 instead of those of a secondary methyl (8-Me; $\delta_{\mathrm{H}} 1.06 /$ $\left.\delta_{\mathrm{C}} 15.5\right)$ in 7 . In the COSY correlations and HMBC correlations, the conectivity of a hydroxymethyl group at C-8 (from $\mathrm{H}_{2}-8$ to C-7) in 5 was confirmed (Supplementary Figure S2). Therefore, the planar structure of 5 was elucidated as shown in Figure 3, and it was designated as mangromicin F, an 8-oxymethylene analog of mangromicin $\mathrm{H}$ (7).

\section{Structure elucidation of mangromicin G (6)}

Mangromicin $\mathrm{G}(\mathbf{6})$ was obtained as a pale yellow powder determined to have the molecular formula of $\mathrm{C}_{22} \mathrm{H}_{34} \mathrm{O}_{7}$ by HRESIMS $[\mathrm{M}+\mathrm{H}]^{+}$ $m / z 411.2385$ (calcd for $\mathrm{C}_{21} \mathrm{H}_{35} \mathrm{O}_{7}, 411.2375$ ). The 1D and 2D NMR spectra of 6 were obtained in $\mathrm{CD}_{3} \mathrm{OD}$.

From a comparison of the ${ }^{1} \mathrm{H}$ and ${ }^{13} \mathrm{C}$ NMR of 6 and 7, the signals of a $n$-propyl $\left(1^{\prime} ; \delta_{\mathrm{H}} 1.61\right.$ and $1.57 / \delta_{\mathrm{C}} 34.2,2^{\prime} ; \delta_{\mathrm{H}} 1.38$ and $1.53 / \delta_{\mathrm{C}} 21.3$, $\left.3^{\prime} ; \delta_{\mathrm{H}} 0.96 / \delta_{\mathrm{C}} 14.2\right)$ and a hydroxymethyl $\left(14-\mathrm{CH}_{2} ; \delta_{\mathrm{H}} 3.47\right.$ and $3.96 / \delta_{\mathrm{C}}$ 65.9) group were observed in 6 instead of those of an ethyl $\left(1^{\prime} ; \delta_{\mathrm{H}} 1.64\right.$ and $\left.1.70 / \delta_{\mathrm{C}} 25.8,2^{\prime} ; \delta_{\mathrm{H}} 1.03 / \delta_{\mathrm{C}} 11.9\right)$ and a tertiary methyl (14-Me; $\delta_{\mathrm{H}}$ $\left.1.34 / \delta_{\mathrm{C}} 25.3\right)$ observed in 7 . In the COSY correlations and HMBC correlations, the connectivity of an $n$-propyl group at C-4 (from $\mathrm{H}_{2}-1^{\prime}$ to $\mathrm{C}-3, \mathrm{C}-4, \mathrm{C}-5$ and $\mathrm{C}-2^{\prime}$, from $\mathrm{H}-4$ to $\mathrm{C}-3$ and $\mathrm{C}-5$ and from $\mathrm{H}-5$ to $\mathrm{C}-4$ and $\mathrm{C}-\mathrm{1}^{\prime}$ ) and a hydroxymethyl group at C-14 (from $\mathrm{H}_{2}-8$ to $\mathrm{C}-13$, C-14 and $\mathrm{C}-15$, and from $\mathrm{H}-13$ and $\mathrm{H}-15$ to $\left.\mathrm{CH}_{2}-8\right)$ in 5 was confirmed (Supplementary Figure S2). Therefore, the planar structure of 6 was elucidated as shown in Figure 3, and it was designated as mangromicin $\mathrm{G}$, a 4-de-ethyl-4-n-propyl-14-oxymethylene of mangromicin $\mathrm{H}$ (7).
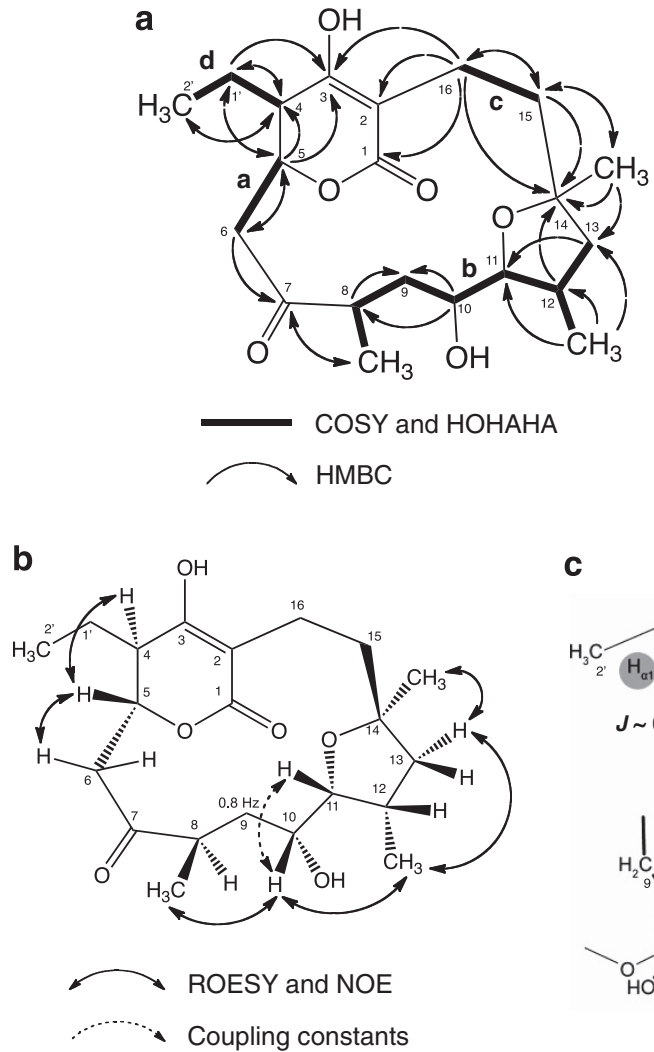

C
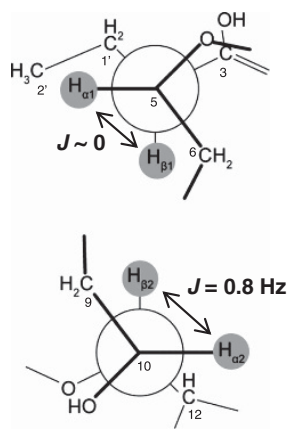

Figure 2 Structure of mangromicin $\mathrm{H}$ (a) ${ }^{1} \mathrm{H}-{ }^{1} \mathrm{H}$ COSY and $\mathrm{HOHAHA}$ correlations (bold) and selected $\mathrm{HMBC}$ correlations (arrow) of mangromicin H (7). (b) Key ROESY and NOE correlations (line) and coupling constants (dot) of mangromicin $\mathrm{H}$ (7). (c) Probable configurations around $\mathrm{H}_{\beta 1}-\mathrm{C} 4-\mathrm{C} 5-$ $\mathrm{H}_{\alpha 1}$ and $\mathrm{H}_{\alpha 2}-\mathrm{C} 10-\mathrm{C} 11-\mathrm{H}_{\beta 2}$ are indicated in Newman projections.

Structure elucidation of mangromicin I (8)

Mangromicin I (8) was obtained as a pale yellow powder determined to have the molecular formula of $\mathrm{C}_{22} \mathrm{H}_{32} \mathrm{O}_{7}$ by HRESIMS $[\mathrm{M}+\mathrm{H}]^{+}$ $m / z 409.2226$ (calcd for $\mathrm{C}_{22} \mathrm{H}_{33} \mathrm{O}_{7}, 409.2222$ ). The 1D and 2D NMR spectra of 7 were obtained in $\mathrm{CD}_{3} \mathrm{OD}$.

From a comparison of the ${ }^{1} \mathrm{H}$ and ${ }^{13} \mathrm{C}$ NMR of 8 and 7 , the signals of a methylene $\left(8-\mathrm{CH}_{2} ; \delta_{\mathrm{H}} 5.68\right.$ and $\left.6.48 / \delta_{\mathrm{C}} 126.6\right)$, one methine (9-CH; $\left.\delta_{\mathrm{H}} 4.20 / \delta_{\mathrm{C}} 82.3\right)$ and methoxy $\left(9-\mathrm{OCH}_{3} ; \delta_{\mathrm{H}} 3.24 / \delta_{\mathrm{C}} 57.0\right)$ group were observed in 8 , instead of those of a secondary methyl $\left(8-\mathrm{Me} ; \delta_{\mathrm{H}} 1.06 / \delta_{\mathrm{C}}\right.$ 15.5) and a methylene $\left(\mathrm{H}_{2}-9 ; \delta_{\mathrm{H}} 1.76\right.$ and 37.7) observed in 7 . In the COSY correlations and HMBC correlations, the conectivity of an exomethylene group at C-8 (from $\mathrm{H}_{2}-8$ to C-7, C-8 and C-9 and from $\mathrm{H}-9$ to $\mathrm{H}_{2}-8$ ) in 8 was confirmed (Supplementary Figure S2). Therefore, the planar structure of $\mathbf{8}$ was elucidated as shown in Figure 3, and it was designated as mangromicin I, an 8-de-methyl-8-exomethylene-9-demethylene-9-methoxy analog of mangromicin $\mathrm{H}$ (7).

\section{Biological activities of mangromicins}

Eight mangromicin analogs were evaluated in a panel of assays, such as antimicrobial activities for pathogenic bacteria and fungi, antivirus activity, cytotoxicity for cancer cells and antiparasitic activity for parasitic protozoa. In consequence, all mangromicin analogs except for mangromicin E (4) and I (8) had more potent scavenging activity against 1,1-diphenyl-2-picrylhydrazyl (DPPH) free radicals than that of $\alpha$-tocopherol. Among the eight compounds, mangromicin A (1) showed the most potent anti-oxidant activity s $\left(\mathrm{IC}_{50}=2.4 \mu \mathrm{M}\right.$, Table 4, Supplementary Figure 3S). 


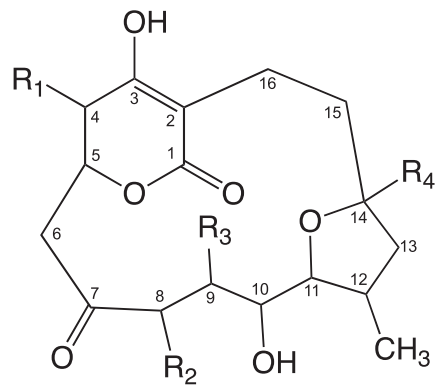<smiles>CCCC1C(=O)C2CCC3(C)CC(C)C(O3)C(O)C=C(C)C(=O)CC1OC2=O</smiles>

\begin{tabular}{ccccc}
\hline Mangromicin & $\mathrm{R}_{1}$ & $\mathrm{R}_{2}$ & $\mathrm{R}_{3}$ & $\mathrm{R}_{4}$ \\
\hline $\mathrm{D}(\mathbf{3})$ & $-\mathrm{CH}_{2} \mathrm{CH}_{2} \mathrm{CH}_{3}$ & $-\mathrm{CH}_{2} \mathrm{OH}$ & $-\mathrm{H}$ & $-\mathrm{CH}_{3}$ \\
$\mathrm{~F}(\mathbf{5})$ & $-\mathrm{C}_{2} \mathrm{H}_{5}$ & $-\mathrm{CH}_{2} \mathrm{OH}$ & $-\mathrm{H}$ & $-\mathrm{CH}_{3}$ \\
$\mathrm{G}(\mathbf{6})$ & $-\mathrm{CH}_{2} \mathrm{CH}_{2} \mathrm{CH}_{3}$ & $-\mathrm{CH}_{3}$ & $-\mathrm{H}$ & $-\mathrm{CH}_{2} \mathrm{OH}$ \\
$\mathrm{H}(\mathbf{7})$ & $-\mathrm{C}_{2} \mathrm{H}_{5}$ & $-\mathrm{CH}_{3}$ & $-\mathrm{H}$ & $-\mathrm{CH}_{3}$ \\
$\mathrm{I}(\mathbf{8})$ & $-\mathrm{C}_{2} \mathrm{H}_{5}$ & $=\mathrm{CH}_{2}$ & $-\mathrm{OCH}_{3}$ & $-\mathrm{CH}_{3}$ \\
\hline
\end{tabular}

Figure 3 Structures of mangromicins D (3), E (4), F (5), G (6), H (7) and I (8).

Table 4 Scavenging effects of mangromicin analogs on DPPH free radicals

\begin{tabular}{lc}
\hline Compound & $\begin{array}{c}\text { DPPH free radical } \\
\text { scavenging activity }\left(\text { I }_{50}, \mu \mathrm{M}\right)\end{array}$ \\
\hline Mangromicin A & $2.4 \pm 0.10$ \\
Mangromicin B & $3.8 \pm 0.03$ \\
Mangromicin D & $3.1 \pm 0.01$ \\
Mangromicin E & $31.1 \pm 0.33$ \\
Mangromicin F & $3.9 \pm 0.05$ \\
Mangromicin G & $6.5 \pm 0.05$ \\
Mangromicin H & $4.1 \pm 0.04$ \\
Mangromicin I & $16.3 \pm 0.15$ \\
$\alpha$-tocopherol & $11.4 \pm 0.77$ \\
\hline
\end{tabular}

In addition, mangromicin analogs were investigated for scavenging activity with respect to nitric oxygen (NO) generated from LPSstimulated RAW264.7 cells, a murine macrophage cell line. All mangromicin analogs (at final concentration of $100 \mu \mathrm{M}$ ) showed no cytotoxic activity against RAW264.7 cells (data not shown). As shown in Figure 4, mangromicin I (7) had the most potent NO scavenging activity. To further understand the effect of mangromicin B (2), which was the second-most potent analog, on the mRNA expression profiles of iNOS in murine macrophage RAW264.7 cells, RT-PCR (reverse transcription-polymerase chain reaction) tests were conducted. As mangromicin I (8) was in short supply, mangromicin B (2) was used for the RT-PCR experiment. Mangromicin B (2) did not attenuate mRNA expression levels of iNOS when compared with LPS-stimulated cells (Supplementary Figure S4). It was therefore suggested that mangromicin B (2) has an ability to scavenge NO generated from LPS-stimulated RAW264.7 cells.

Interestingly, the anti-oxidant activity of mangromicin E (4) was reduced about 10 times than that of mangromicin B (2). As mangromicin E (4) had a carbonyl group at the C-3 position instead of hydroxy group of mangromicin B (2), it was suggested that the hydroxy group at the C-3 position is important in the scavenging activity for DPPH free radicals. Conversely, mangromicins B (2), E (4) and I (8) showed more potent NO scavenging activity among the analogs tested. As these three analogs had an $\alpha, \beta$-unsaturated ketone carbonyl group at the C-7 position, it was suggested that this common partial structure is important in the NO scavenging activity.

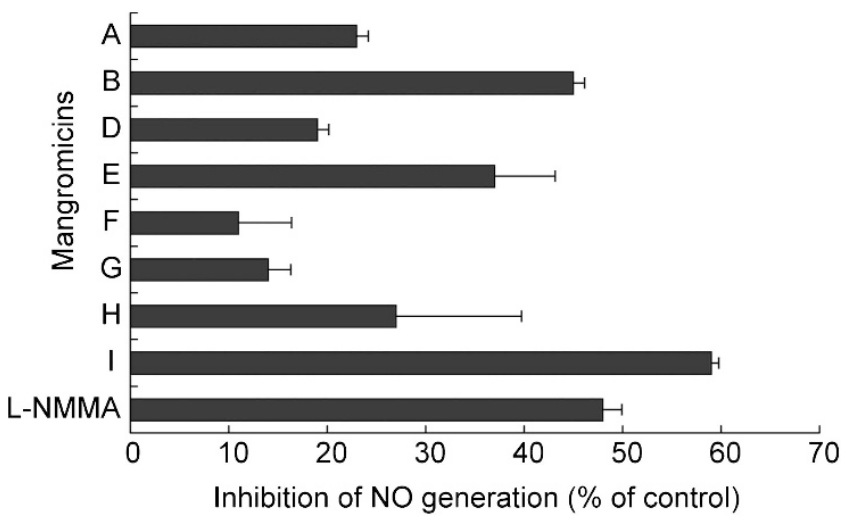

Figure 4 Scavenging effects of mangromicin analogs on NO generated from LPS-stimulated a murine macrophage RAW264.7 cell line.

Thus, there was poor correlation between DPPH free radical scavenging activity and NO scavenging activity in mangromicin analogs. Therefore, the functional site for radical scavenging activity in mangromicin analogs may be different according to radical species.

\section{METHODS}

\section{General experimental procedures}

NMR spectra were measured using an Agilent Technologies NMR System 400 and INOVA 600 (Varian Co., Palo Alto, CA, USA) or JEOL JNM-ECA 500 spectrometer (JEOL Ltd., Tokyo, Japan), with ${ }^{1} \mathrm{H}-\mathrm{NMR}$ at 400 , 500 or $600 \mathrm{MHz}$ and ${ }^{13} \mathrm{C}-\mathrm{NMR}$ at 100,125 or $150 \mathrm{MHz}$ in $\mathrm{CD}_{3} \mathrm{OD}$ or DMSO- $d_{6}$. The chemical shifts are expressed in p.p.m. and are referenced to residual $\mathrm{CD}_{3} \mathrm{OD}$ (3.31 p.p.m.) or DMSO- $d_{6}$ (2.48 p.p.m.) in the ${ }^{1} \mathrm{H}-\mathrm{NMR}$ spectra and $\mathrm{CD}_{3} \mathrm{OD}$ ( 49 p.p.m.) or DMSO- $d_{6}$ (39.5 p.p.m.) in the ${ }^{13} \mathrm{C}-\mathrm{NMR}$ spectra. LCESI-MS spectra were measured using an AB Sciex QSTAR Hybrid LC/MS/MS Systems (AB Sciex, Framingham, MA, USA). IR spectra $(\mathrm{KBr})$ were taken on a Horiba FT-710 Fourier transform IR spectrometer (Horiba Ltd, Kyoto, Japan). UV spectra were measured with a Hitachi U-2810 spectrophotometer (Hitachi High-Technologies Co., Tokyo, Japan). Optical rotation was measured on a JASCO model DIP-1000 polarimeter (Jasco Co., Tokyo, Japan). Fluorescence was monitored using a Corona Grating Microplate Reader SH-9000 Lab (Corona Electric Co., Ltd., Ibaraki, Japan).

\section{Reagents}

Reagents were purchased from the following sources: LPS was purchased from Sigma-Aldrich Co. (St Louis, MO, USA). DPPH, IFN- $\gamma$ and NG-monomethyl- 
L-arginine were purchased from Wako Pure Chemical Industries Ltd. (Osaka, Japan). Diaminofluorescein-2 (DAF-2) was purchased from Sekisui Medical Co., Ltd. (Tokyo, Japan). All other reagents used were of analytical grade.

\section{Fermentation}

The strain K10-0216 was grown and maintained on agar slants consisting of $1.0 \%$ starch, $0.3 \% \mathrm{NZ}$ amine, $0.1 \%$ yeast extract, $0.1 \%$ meat extract, $1.2 \%$ agar and $0.3 \% \mathrm{CaCO}_{3}$. A loop of spores of strain $\mathrm{K} 10-0216$ was inoculated into $100 \mathrm{ml}$ of seed medium, consisting of $2.4 \%$ starch, $0.1 \%$ glucose, $0.3 \%$ peptone, $0.3 \%$ meat extract, $0.5 \%$ yeast extract and $0.4 \% \mathrm{CaCO}_{3}$ (adjusted to $\mathrm{pH} 7.0$ before sterilization) in a 500-ml Erlenmeyer flask. The flask was incubated on a rotary shaker $\left(210\right.$ r.p.m.) at $27^{\circ} \mathrm{C}$ for 3 days. A 1-ml portion of the seed culture was transferred to 500-ml Erlenmeyer flasks (total 150) containing $100 \mathrm{ml}$ of starch medium, consisting of $5.0 \%$ soluble starch, $0.5 \%$ glycerol, $1.0 \%$ de-fatted wheat germ, $1.0 \%$ dry yeast and $0.3 \% \mathrm{CaCO}_{3}$ (adjusted to $\mathrm{pH} 7.0$ before sterilization) and fermentation was carried out on a rotary shaker $\left(210\right.$ r.p.m.) at $27^{\circ} \mathrm{C}$ for 7 days.

\section{Biological activities of mangromicins}

Effect of mangromicins on DPPH free radicals: antioxidative activity was estimated by the DPPH free radical scavenging method, as described previously with a minor modification. ${ }^{14} \mathrm{DPPH}$ was dissolved in dimethylformamide $\left(10 \mathrm{mg} \mathrm{ml}^{-1}\right)$ and then diluted to $120 \mu \mathrm{moll}^{-1}$ with $0.1 \mathrm{moll}^{-1}$ Tris- $\mathrm{HCl}$ buffer ( $\mathrm{pH}$ 7.6) containing 5\% Triton X-100. Ten microliters of the sample solution was then added to $90 \mu \mathrm{l}$ of a DPPH solution. After incubation for $30 \mathrm{~min}$ in the dark at room temperature, the absorbance at $517 \mathrm{~nm}$ was measured with a microplate reader (Corona Electric).

Effect of mangromicins on NO production generated from LPS-stimulated RAW 264.7 cells: RAW 264.7 cells (a mouse macrophage cell line) were obtained from the American Type Culture Collection (Rockville, MD, USA). Raw 264.7 cells were grown in Dulbecco's modified Eagle's medium supplemented with $10 \%$ fetal bovine serum, streptomycin $\left(100 \mathrm{Uml}^{-1}\right)$ and penicillin $\mathrm{G}\left(100 \mathrm{U} \mathrm{ml}^{-1}\right)$ at $37^{\circ} \mathrm{C}$ in an atmosphere of $5 \% \mathrm{CO}_{2}$ and $95 \%$ air, as described previously. ${ }^{15}$

RAW 264.7 cells were plated in wells of a 96-well microplate $\left(1 \times 10^{5}\right.$ cells/ well), and were cultured for $6 \mathrm{~h}$ to make macrophages adherent. Cells were subsequently cultured for $16 \mathrm{~h}$ with $200 \mu \mathrm{l}$ of fresh medium containing LPS $\left(100 \mathrm{ng} \mathrm{ml}^{-1}\right)$ and IFN- $\gamma\left(10 \mathrm{U} \mathrm{ml}^{-1}\right)$. The activated cells adherent in wells were washed twice with KRP (Krebs-Ringer-Phosphate) buffer, $200 \mu \mathrm{l}$ of medium containing each mangromicin analog (a final concentration at $100 \mu \mathrm{moll}^{-1}$ ) diluted in DMSO with $1 \mathrm{~mm}$ L-arginine and $10 \mu \mathrm{M}$ DAF-2 was added to each well. DAF-2, a sensitive fluorescent indicator, was used for the detection of NO. ${ }^{16,17}$ The final DMSO concentration was $<0.1 \%$. At this concentration, DMSO did not show any NO-induction without stimulation with LPS. After incubation for $2 \mathrm{~h}$, the supernatants were transferred to black microplates and the florescence was measured with a microplate reader (Corona Electric) calibrated for excitation at $495 \mathrm{~nm}$ and emission at $515 \mathrm{~nm}$.

\section{ACKNOWLEDGEMENTS}

This study was supported, in part, by funds from Quality Assurance Framework of Higher Education from the Ministry of Education, Culture, Sports, Science and Technology (MEXT), Japan, and the Institute for Fermentation (IFO), Osaka, Japan. We are grateful to Ms Noriko Sato and Dr Kenichiro Nagai, School of Pharmacy, Kitasato University, for measurements of NMR and MS spectra and Ms Megumi Niitsuma, Kitasato Institute for Life Sciences, Kitasato University, for RT-PCR measurements.

1 Newman, D. J. \& Gordon, M. C. Natural products as sources of new drugs over the 30 years from 1981 to 2010. J. Nat. Prod. 75, 311-335 (2012).

2 Ghisalberti, E. L. Detection and isolation of bioactive natural products. Bioactive Natural Products (Eds Molyneux, R. J. \& Colegate, S. M.) 11-76 (CRC Press, Boca Raton, FL, 2007).

3 Umezawa, H. et al. Production and isolation of a new antibiotic: kanamycin. J. Antibiot. 10, 181-188 (1957).

4 Hata, T. et al. Leucomycin, a new antibiotic. J. Antibiot. 6, 87-89 (1953).

5 Burg, R. W. et al. Avermectins, new family of potent anthelmintic agents: producing organism and fermentation. Antimicrob. Agents Chemother. 15, 361-367 (1979).

6 Nakashima, T. et al. Trehangelins A, B and C, novel photo-oxidative hemolysis inhibitors produced by an endophytic actinomycete, Polymorphospora rubra K070510. J. Antibiot. 66, 311-317 (2013).

7 Nakashima, T. et al. Mangromicins A and B: structure and anti-trypanosomal activity of two new cyclopentadecane compounds from Lechevalieria aerocolonigenes K10-0216. J. Antibiot. 67, 253-260 (2013).

8 Ōmura, S. et al. A new alkaloid AM-2282 OF Streptomyces origin. Taxonomy, fermentation, isolation and preliminary characterization. J. Antibiot. 30, 275-282 (1977).

9 Ōmura, S. et al. A new antibiotic, AM-2504. Agric. Biol. Chem. 41, 1827-1828 (1977).

10 Ōmura, S. et al. Novel mangromycin compound and production method therefor. Japan Patent 2011-191404 (2011)

11 Ömura, S. et al. Novel mangromycin compound and production method therefor. WO 2013031239 (2013).

12 Kamiya, Y. et al. Structural analysis and biological activities of mangromicin analogs. Abstracts of Papers of the 28th Annual Meeting of the Society for Actinomycetes Japan 0-21 (The society for Actinomycetes Japan, Hiroshima, Japan, 2013).

13 Igarashi, Y. et al. Akaeolide, a carbocyclic polyketide from marine-derived Streptomyces. Org. Lett. 15, 5678-5681 (2013).

14 Nakashima, T. et al. Inhibitory or scavenging action of ketoconazole and ciclopiroxolamine against reactive oxygen species released by primed inflammatory cells. Br. J. Dermatol. 156, 720-727 (2007).

15 Nakashima, T., Kurachi, M., Kato, Y., Yamaguchi, K. \& Oda, T. Characterization of bacterium isolated from the sediment at coastal area of Omura Bay in Japan and several biological activities of pigment produced by this isolate. Microbiol. Immunol. 49, 407-415 (2005).

$16 \mathrm{Kojima}, \mathrm{H}$. et al. Development of a fluorescent indicator for nitric oxide based on the fluorescein chromophore. Chem. Pharm. Bull. 46, 373-375 (1998).

17 Nakatsubo, N. et al. Direct evidence of nitric oxide production from bovine aortic endothelial cells using new fluorescence indicators: diaminofluoresceins. FEBS Lett. 427, 263-266 (1998).

Supplementary Information accompanies the paper on The Journal of Antibiotics website (http://www.nature.com/ja) 